\title{
PENGARUH MOTIVASI DAN DISIPLIN KERJA TERHADAP KINERJA KARYAWAN PADA CV MUSTY JAYA
}

\author{
Raja Saul Marto Hendry, Daslan Simanjuntak \\ Fakultas Ekonomi dan Bisnis Universitas Labuhanbatu \\ Email : rajasaul365@gmail.com
}

\begin{abstract}
ABSTRAK
Penelitian ini bertujuan untuk menganalisis pengaruh motivasi dan disiplin kerja terhadap kinerja karyawan pada pada CV Musty Jaya. Dalam penelitian ini mengambil sampel sebanyak 30 karyawan, jenis data dan sumber data yang digunakan dalam penelitian ini dengan menggunakan data primer yang didapat dari wawancara dan jawaban responden berupa pengisian kuesioner yang disebarkan kepada karyawan CV Musty Jaya. Adapun Uji istrumen yang digunakan untuk menguji layak atau tidaknya suatu pertanyaan adalah uji Validitas dan uji Reliabilitas. Metode analisis data yang digunakan dalam penelitian ini adalah analisis regresi berganda, uji $F$, uji $t$, dan uji koefisien determinasi. Sebelumnya dilakukan uji asumsi klasik berupa uji multikolonieritas, uji heteroskedastisitas, dan uji normalitas. Hasil penelitan menunjukan bahwa adanya pengaruh antara motivasi dan disiplin kerja terhadap kinerja karyawan yang signifikan. Dari kedua variabel tersebut variabel disiplin kerja berpengaruh lebih besar terhadap kinerja karyawan dibandingkan dengan motivasi. Dengan adanya penelitian ini dapat disimpulkan bahwa karyawan memerlukan motivasi dan pendisiplinan dalam meningkatkan kinerja, terutama perusahaan harus lebih meningkatkan motivasi kerja kepada karyawan CV Musty Jaya.
\end{abstract}

Kata Kunci : Motivasi, Disiplin Kerja, Kinerja Karyawan

\section{PENDAHULUAN}

\section{A. Latar Belakang Masalah}

Sumber daya manusia manusia memiliki posisi sangat strategis dalam organisasi, artinya unsur manusia memegang peranan penting dalam melakukan aktivitas untuk mencapai tujuan. Untuk itulah eksistensi sumber daya manusia dalam organisasi sangat kuat (Ambar Teguh Sulistiyani dan Rosidah, 2006). Manusia selalu berperan aktif dan dominan dalam setiap kegiatan organisasi karena manusia menjadi perencana, pelaku, dan penentu terwujudnya tujuan organisasi. Tujuan tidak mungkin terwujud tanpa peran aktif karyawan meskipun alatalat yang dimiliki perusahaan begitu canggihnya (Hasibuan,2010).

Oleh karena itu keberhasilan suatu perusahaan tidak hanya tergantung dengan teknologi perusahaan melainkan juga tergantung pada aspek sumber daya manusia yang dimiliki oleh perusahaan. Sehingga suatu perusahaan membutuhkan sumber daya manusia yang potensial, baik pemimpin maupun karyawan dapat memberikan kontribusi yang baik dan melaksanakan tugas dengan optimal untuk mencapai tujuan perusahaan. Karena semua kegiatan perusahaan akan melibatkan tindakan sumber daya manusia yang ada didalamnya.

Keberhasilan suatu organisasi dipengaruhi oleh kinerja individu pegawainya, suatu organisasi akan berupaya untuk meningkatkan kinerja pegawainya dengan harapan tujuan perusahaan dapat tercapai. Kinerja pada dasarnya adalah apa yang dilakukan atau tidak dilakukan karyawan. Kinerja karyawan adalah yang mempengaruhi seberapa banyak mereka memberi kontribusi kepada organisasi antara lain termasuk kuantitas output, kualitas output, jangka waktu output, kehadiran di tempat kerja dan sikap kooperatif (Mathis dan Jackson, 2008). Kinerja adalah hasil atau tingkat keberhasilan seseorang secara keseluruhan selama 
periode tertentu dalam melaksanakan tugas dibandingkan dengan berbagai kemungkinan standar hasil kerja, target atau sasaran atau kriteria yang ditentukan terlebih dahulu dan telah disepakati bersama (Rivai, 2008).

Kinerja menurut Prabu (2006) bahwa kinerja karyawan (prestasi kerja) adalah hasil kerja secara kualitas dan kuantitas yang tercapai oleh seseorang karyawan dalam melaksanakan tugasnya sesuai tanggungjawab yang diberikan kepadanya. Dengan demikian, kinerja merupakan hal yang penting bagi organisasi atau perusahaan serta dari pihak pegawai itu sendiri. Oleh karena itu, kinerja karyawan akan berjalan dengan efektif apabila didukung dengan motivasi dan disiplin kerja.

Motivasi adalah keinginan dalam diri seseorang yang menyebabkan orang tersebut bertindak. Orang bertindak karena satu alasan yaitu untuk mencapai tujuan. Jadi, motivasi adalah sebuah dorongan yang diatur oleh tujuan dan jarang muncul dalam kekosongan (Mathis dan Jackson, 2009). Sedangkan menurut Supardi dan Anwar (2006) mengatakan motivasi adalah keadaan dalam pribadi seseorang yang mendorong keinginan individu untuk melakukan kegiatan - kegiatan tertentu guna mencapai tujuan.

Pemberian motivasi sangat penting dalam setiap perusahaan. Karyawan yang mempunyai motivasi kerja yang tinggi akan dapat mendorong karyawan tersebut bekerja lebih semangat serta dapat memberikan kontribusi positif terhadap pekerjaan yang telah menjadi tanggungjawabnya. Motivasi kerja dalah sesuatu yang menimbulkan dorongan atau semangat kerja atau dengan kata lain pendorong semangat kerja (Martoyo,2006). Tanpa motivasi, seorang karyawan tidak dapat memenuhi pekerjaannya sesuai standar atau melampui standar karena apa yang menjadi motivasi dalam bekerja tidak terpenuhi.

Sekalipun seorang karyawan yang memiliki kemampuan dalam bekerja tinggi tetapi tidak memiliki motivasi untuk menyelesaikan tugasnya maka hasil akhir dalam pekerjaannya tidak akan memuaskan. Untuk menciptakan kinerja karyawan agar berjalan dengan efektif, hal tersebut tidak hanya didorong dengan adanya motivasi saja tetapi dengan mempunyai disiplin kerja yang tinggi. Disiplin adalah prosedur yang mengoreksi atau menghukum bawahan karena melanggar peraturan atau prosedur.

Disiplin merupakan bentuk pengendalian diri pegawai dan pelaksanaan yang teratur dan menunjukan tingkat kesungguhan tim kerja didalam sebuah organisasi (Ambar Teguh Sulistiyani dan Rosidah, 2006). Nitisemito (2006) mengemukakan disiplin sebagai suatu sikap, perilaku dan perbuatan yang sesuai dengan peraturan dari perusahaan, baik tertulis maupun tidak tertulis. Disiplin merupakan tindakan manajemen untuk mendorong para anggota organisasi memenuhi tuntutan berbagai ketentuan yang harus ditaati oleh karyawan.

Pendisiplinan pegawai adalah suatu bentuk pelatihan yang berusaha memperbaiki dan membentuk pengetahuan, sikap dan perilaku karyawan sehingga para karyawan dapat bekerja secara kooperatif dengan karyawan yang lain serta meningkatkan prestasi kerjanya (Sondang P. Siagian,2008).

Dengan karyawan mematuhi peraturan yang telah ditetapkan oleh perusahaan dan mempunyai disiplin yang tinggi maka akan menciptakan suasana perusahaan lebih kondusif sehingga akan berdampak positif pada aktivitas perusahaan. Oleh karena itu, setiap perusahaan mempunyai harapan agar karyawan perusahaan dapat mematuhi peraturan yang telah ditetapkan.

Untuk menciptakan kinerja karyawan yang efektif dan efisien tidak mudah, tidak hanya menciptakan disiplin kerja yang tinggi saja tetapi faktor motivasi juga mempengaruhi. Oleh karena itu, perusahaan dapat mendorong karyawan agar memiliki motivasi yang tinggi untuk mencapai tujuan perusahaan. CV Musty Jaya mendorong karyawannya agar memiliki motivasi dalam menjalankan kegiatannya dengan memberikan reward kepada karyawan yang memenuhi target bahkan melampui target yang telah ditetapkan. Tidak hanya reward saja yang digunakan perusahaan dalam meningkatkan motivasi, tetapi kenaikan gaji, tunjangan dan 
promosi kerja yang tetap dipertimbangkan dengan kemampuan yang dimiliki oleh karyawan juga merupakan cara untuk meningkatkan motivasi karyawan CV Musty Jaya. Penilaian kinerja individu pada CV Musty Jaya yaitu nilai angka akhir yang mencerminkan kontribusi karyawan terhadap hasil keseluruhan dari performansi unit kerja, dan disebut dengan Prestasi (P). Penilaian kinerja individu berdasarkan suatu pernyataan mengenai sasaran kerja yang hendak dicapai yang telah ditargetkan oleh seorang karyawan dalam satu periode dan disepakati oleh atasannya yang disebut dengan SKI (Sasaran Kerja Individu). Nilai Prestasi (NP) dihasilkan melalui konversi sebagai berikut:

Berdasarkan latar belakang masalah tersebut, maka penulis tertarik untuk mengadakan penelitian lebiha lanjut dalam bentuk skripi dengan judul Pengaruh motivasi dan disiplin kerja terhadap kinerja karyawan pada CV Musty Jaya.

\section{B. Batasan Dan Rumusan Masalah}

\section{Batasan Masalah}

Untuk memperjelas masalah yang diteliti dan dengan mempertimbangkan keterbatasanketerbatasan yang ada pada penulis, maka dibuat batasan yang bertujuan untuk menghindari kekeliruan dan menafsirkan judul peneliti. Mengingat luasnya lingkup kajian penelitian yang dipaparkan dalam judul peneliti, maka dalam penulisan dibatasi pada beberapa hal, yaitu objek penelitian ini adalah bagaimana Pengaruh motivasi dan disiplin kerja terhadap kinerja karyawan pada CV Musty Jaya.

\section{Rumusan Masalah}

Berdasarkan latar belakang yang telah diuraikan maka penelitian ini mengemukakan rumusan masalah sebagai beriku :

1. Seberapa besar motivasi mempunyai pengaruh terhadap kinerja karyawan pada CV Musty Jaya

2. Seberapa besar disiplin kerja mempunyai pengaruh terhadap kinerja karyawan pada CV Musty Jaya

3. Seberapa besar motivasi dan disiplin kerja mempunyai pengaruh terhadap kinerja karyawan pada CV Musty Jaya

\section{Tujuan Penelitian}

Adapaun tujuan dalam penelitian ini adalah :

1. Untuk membuktikan secara empiris motivasi sebagai kerangka dasar teori kerja karyawan dalam mencapai kinerja karyawan pada CV Musty Jaya.

2. Untuk membuktikan secara empiris pengaruh disiplin kerja terhadap kinerja karyawan pada CV Musty Jaya.

3. Untuk membuktikan secara empiris motivasi dan disiplin kerja terhadap kinerja karyawan pada CV Musty Jaya.

\section{Manfaat Penelitian}

Adapaun manfaat penelitian ini antara lain adalah :

1. Bagi peneliti, untuk menambah pengetahuan tentang Pengaruh motivasi dan disiplin kerja terhadap kinerja karyawan, serta membandingkan teori yang ada dengan kenyataan yang ada di lapangan usaha/perusahaan.

2. Bagi perusahaan, sebagai bahan masukan bagi perusahaan, baik karyawan maupun pimpinan perusahaan dalam menjalankan roda perusahaan.

3. Bagi Sekolah Tinggi Ilmu Ekonomi (STIE), sebagai referensi untuk pengembangan penelitian tentang motivasi dan disiplin kerja terhadap kinerja karyawan dalam perusahaan 


\section{TINJAUAN PUSTAKA}

\section{Motivasi}

Motivasi adalah hal yang menyebabkan, menyalurkan, dan mendukung perilaku manusia, supaya mau bekerja giat dan antusias mencapai hasil yang optimal. Motivasi semakin penting karena manajer membagikan pekerjaan pada bawahannya untuk dikerjakan dengan baik dan terintegrasi kepada tujuan yang ditentukan (Hasibuan, 2003). Setiap kegiatan yang dilakukan oleh seseorang didorong oleh suatu kekuatan dari dalam diri seseorang, kekuatan pendorong inilah yang disebut motivasi (Fuad Masee ud, 2002).

Menurut Robbins (2012) motivasi sebagai proses yang menjelaskan intensitas, arah, dan ketekunan seorang individu untuk mencapai tujuannya. Suasana batin atau psikologis seorang pekerja sebagai individu dalam masyarakat organisasi atau perusahaan yang menjadi lingkungan kerjanya, sangat besar pengaruhnya pada pelaksanaan pekerjaannya. Suasana batin itu terlihat dalam semangat atau gairah kerja yang menghasilkan kegiatan kerja sebagai kontribusi bagi pencapaian tujuan bisnis perusahaan (Hadari Nawawi, 2005).

Menurut Adella Hotyda Siregar (2007) bahwa motivasi kerja adalah sesuatu yang menimbulkan keinginan bagi seseorang atau pekerja, baik yang berasal dari dalam dirinya maupun yang berasal dari luar untuk melaksanakan pekerjaan atau kegiatan dengan rasa tanggung jawab guna mencapau tujuan yang diinginkan.

\section{Disiplin kerja}

Disiplin Kerja sangatlah penting bagi suatu perusahaan atau instansi pemerintah dalam rangka mewujudkan tujuan perusahaan. Tanpa adanya Disiplin Kerja yang baik sulit bagi suatu perusahaan untuk mencapai hasil yang optimal. Disiplin yang baik mencerminkan besarnya tanggung jawab seseorang terhadap tugastugas yang diberikan kepadanya.

Menurut Singodimejo (dalam H. Edy Sutrisno, 2010), disiplin adalah sikap kesediaan dan kerelaan seseorang untuk mematuhi dan menaati norma-norma peraturan yang berlaku di sekitarnya. Menurut B. Siswanto Sastrohadiwiryo (2002; 291) Disiplin Kerja adalah sebagai suatu sikap menghormati, menghargai, patuh dan taat terhadap peraturan-peraturan yang berlaku, baik yang tertulis maupun yang tidak tertulis serta sangggup menjalankannnya dan tidak mengelak untuk menerima sanksi-sanksi apabila ia melanggar tugas dan wewenang yang diberikan kepadanya.

Dari definisi di atas dapat disimpulkan bahwa Disiplin Kerja adalah sikap kesediaan dan kerelaan seseorang untuk patuh dan taat terhadap peraturan-peraturan yang berlaku, baik yang tertulis maupun yang tidak tertulis serta sangggup menjalankannnya dan tidak mengelak untuk menerima sanksi-sanksi apabila ia melanggar tugas dan wewenang yang diberikan kepadanya.

Pengertian disiplin sebagai suatu ketaatan seseorang atau kelompok terhadap peraturan yang telah ditetapkan. Displin berkaitan dengan kesadaran dan sikap mental seseorang atau kelompok dalam mentaati peraturan yang berlaku. Menurut Mathis dan Jackson (2001), menyatakan disiplin adalah bentuk pelatihan yang menegakkan peraturan peraturan perusahaan.

\section{Kinerja Karyawan}

Setiap perusahaan atau instansi selalu berusaha agar karyawan berprestasi dalam bentuk memberikan kinerja yang baik. Kinerja Karyawan bagi perusahaan sangat penting sebagai alat pengukur keberhasilan dalam menjalankan usahanya, karena Kinerja Karyawan adalah hasil kerja dari karyawan tersebut yang menunjukkan keberhasilan mereka dalam menjalankan tugasnya. Semakin tinggi Kinerja Karyawan maka semakin baik pula kinerja perusahaan atau instansi tersebut.

Menurut Wilson Bangun (2012: 231) Kinerja Karyawan (performance) adalah hasil pekerjaan yang dicapai seseorang berdasarkan persyaratan-persyaratan pekerjaan. Menurut Suyadi Prawirosentono (2008:2) Kinerja Karyawan (performance) adalah hasil kerja yang 
dicapai oleh seseorang atau sekelompok orang dalam suatu organisasi, sesuai dengan wewenang dan tanggung jawab masingmasing.

Menurut A. A Anwar Prabu Mangkunegara (2010: 9) Kinerja Karyawan (prestasi kerja) adalah hasil kerja secara kualitas dan kuantitas yang dicapai oleh seseorang karyawan dalam melaksanakan tugasnya sesuai tanggung jawab yang diberikan kepadanya. Dari beberapa pengertian di atas dapat disimpulkan bahwa Kinerja Karyawan adalah perbandingan hasil kerja secara kualitas dan kuantitas yang dicapai oleh seorang karyawan dalam melaksanakan tugasnya dengan standar kerja yang telah ditetapkan oleh pihak organisasi.

Nawawi (2005) menyatakan bahwa, "Kinerja adalah hasil pelaksanaan suatu pekerjaan, baik bersifat fisik/material maupun non fisik/non material". Selanjutnya Mathis dan Jackson (2006) menyatakan bahwa, "Kinerja (performance) pada dasarnya adalah apa yang dilakukan atau tidak dilakukan oleh karyawan. Kinerja karyawan yang umum untuk kebanyakan pekerjaan meliputi elemen sebagai berikut: (1) kuantitas dari hasil, (2) kualitas dari hasil, (3) ketepatan waktu dari hasil, (4) kehadiran, dan (5) kemampuan bekerja sama.". Simanjuntak (2005), menyatakan bahwa "kinerja adalah tingkat pencapaian hasil atas pelaksanaan tugas tertentu. Simanjuntak juga mengartikan kinerja individu sebagai tingkat pencapaian atau hasil kerja seseorang dari sasaran yang harus dicapai atau tugas yang harus dilaksanakan dalam kurun waktu tertentu". Selain itu Foster dan Seeker (2001) juga menyatakan bahwa, "Kinerja adalah hasil yang dicapai seseorang menurut ukuran yang berlaku untuk pekerjaan yang bersangkutan".

\section{Hubungan Antar Variabel}

\section{Hubungan antara Motivasi terhadap Kinerja Karyawan}

Motivasi merupakan rangsangan dari luar dalam bentuk benda atau bukan benda yang dapat menumbuhkan dorongan pada orang untuk memiliki, menikmati, menguasai atau mencapai benda atau bukan benda tersebut. Motivasi seseorang melakukan pekerjaan karena memiliki tujuan untuk memenuhi kebutuhan hidupnya. Seseorang akan merasakan kekhawatiran apabila kebutuhan hidupnya tidak tercapai sehingga hal tersebut akan mempengaruhi dalam diri individu untuk lebih meningkatkan motivasinya. Menurut Robbins (2008) motivasi merupakan keinginan untuk melakukan sesuatu dan menentukan kemampuan bertindak untuk memuaskan kebutuhan individu.

Dengan segala kebutuhan tersebut, seseorang dituntut untuk bekerja lebih giat dan aktif dalam bekerja, karena dengan seseorang memiliki motivasi yang tinggi dalam melakukan pekerjaannya maka kinerja seseorang didalam perusahaan akan meningkat dan target perusahaan dapat tercapai. Abdul Hakim (2006) menyebutkan salah satu faktor yang mempengaruhi kinerja karyawan yaitu faktor motivasi, dimana motivasi merupakan kondisi yang menggerakan seseorang berusaha untuk mencapai tujuan atau mencapai hasil yang diinginkan.

\section{Hubungan Disiplin kerja terhadap Kinerja Karyawan}

Menurut Moenir (2004) disiplin kerja pada dasarnya selalu diharapkan menjadi ciri setiap SDM dalam organisasi, karena dengan kedisiplinan organisasi akan berjalan dengan baik dan bisa mencapai tujuannya dengan baik pula. Setiap karyawan harus memiliki disiplin kerja didalam organisasi atau perusahaannya, seperti mematuhi peraturan tertulis maupun tidak tertulis yang telah di tetapkan oleh perusahaan karena hal tersebut dapat menciptakan lingkungan kerja yang kondusif dan harmonis sehingga akan memberikan dampak yang positif terhadap kinerja karyawannya.

Berdasarkan hasil penelitian Syarif (2004) tentang motivasi dan kinerja di lingkungan pemerintahan yag menyebutkan bahwa tidak optimalnya kinerja karyawan disebabkan oleh banyaknya karyawan bermotivasi buruk dalam kerja, juga banyaknya karyawan yang tidak disiplin dalam bekerja. Menurut Susiarto dan Ahmadi (2006), disiplin kerja karyawan bagian 
dari faktor kinerja. Prasetyo (2008) menyatakan bahwa salah satu faktor penentu dari efektifitas kinerja adalah disiplin kerja.

Disiplin kerja harus dimiliki setiap karyawan dan harus dibudayakan di kalangan karyawan agar bisa mendukung tercapainya tujuan organisasi karena merupakan wujud dari kepatuhan terhadap aturan kerja dan juga sebagai tanggung jawab diri terhadap perusahaan. Berdasarkan uraian diatas, maka hipotesis yang diajukan dalam penelitian ini adalah: Disiplin kerja karyawan berpengaruh postif terhadap kinerja karyawan.

\section{HASIL PENELITIAN DAN PEMBAHASAN 1 Uji Normalitas}

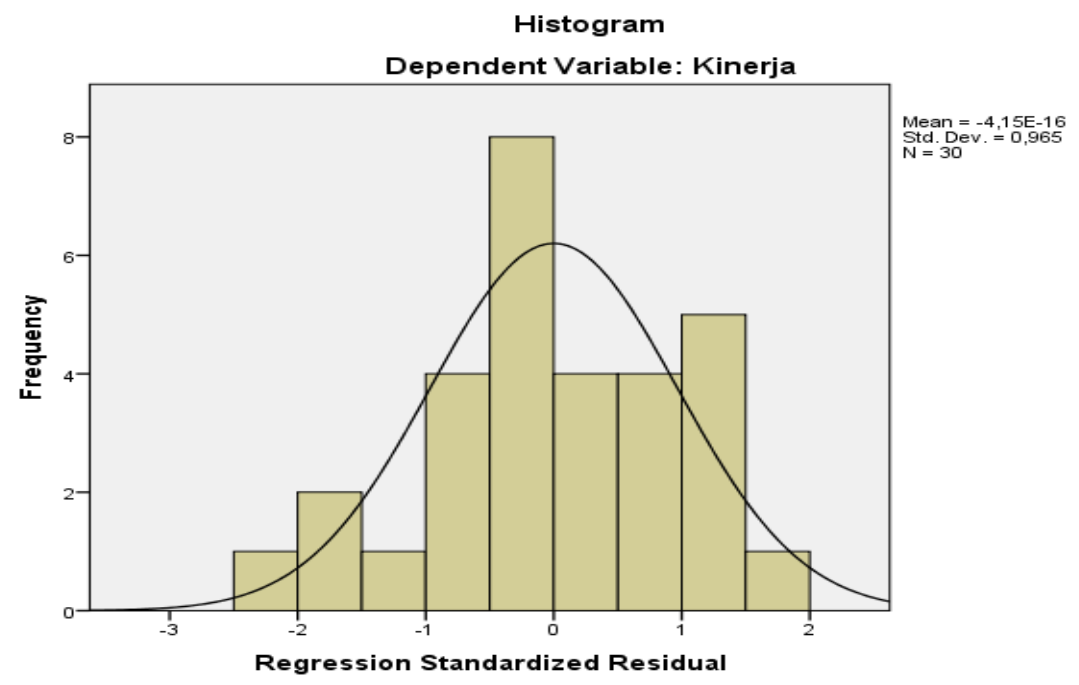

Berdasarkan grafik diatas dapat diketahui bahwa data yang normal memiliki bentuk seperti lonceng. Karena data menyebar disekitar garis diagonal dan mengikuti arah garis diagonal atau grafik histogramnya menunjukkan pola distribusi normal, maka model regresi memenuhi asumsi normal.

\section{Uji Multikolinearitas}

Uji multikolinearitas digunakan untuk menguji adanya hubungan linear yang sempurna (mendekati sempurna) antara beberapa atau semua variabel bebas.

\section{Tabel 4.10}

Uji Multikolinearitas

\section{Coefficients ${ }^{\mathrm{a}}$}

\begin{tabular}{|ll|r|r|}
\hline \multirow{2}{*}{ Model } & \multicolumn{2}{|c|}{ Collinearity Statistics } \\
\cline { 3 - 4 } & Tolerance & \multicolumn{1}{c|}{ VIF } \\
\hline 1 & Constant) & & \\
& Motivasi &, 767 & 1,894 \\
& disiplin kerja &, 767 & 1,894 \\
\hline
\end{tabular}

a. Dependent Variable: Kinerja

Sumber: Out put SPSS, data diolah (2016)

Dasar pengambilan keputusan berdasarkan nilai tolerance:

a. Tolerance $>0,1$ maka tidak terjadi multikolinearitas

b. Tolerance $<0,1$ maka terjadi multikolinearitas

Dasar pengambilan keputusan berdasarkan nilai VIF:

a. VIF $<10$ maka tidak terjadi multikolinearitas 
b. VIF > 10 maka terjadi multikolinearitas

Dari tabel uji multikolinearitas diketahui bahwa nilai tolerance motivasi yaitu 0,767 > 0,1 maka tidak terjadi multikolinearitas, disiplin kerja yaitu $0,767>0,1$ maka tidak terjadi multikolinearitas.

Berdasarkan uji multikolinearitas diketahui bahwa nilai VIF dari motivasi yaitu 1,894 $<10$ maka tidak terjadi multikolinearitas, nilai VIF disiplin kerja yaitu 1,894 < 10 maka tidak terjadi multikolinearitas.

\section{Uji Heteroskedastisitas}

Uji heteroskedastisitas digunakan untuk mendeteksi apakah dalam model regresi terjadi ketidaksamaan varian dari residual satu pengamatan ke pengamatan lain. Jika varians dari resiudal satu pengamatan ke pengamatan yang lain tetap, maka disebut homokedastisitas dan jika berbeda disebut heteroskedastisitas. Model regresi yang baik adalah yang homokedastisitas atau tidak terjadi heteroskedastisitas.

Uji heteroskedastisitas dilakukan dengan menganalisis penyebaran titik-titk yang terdapat pada Scatterplot yang dihasilkan program SPSS dengan dasar pengambilan keputusan.

$$
\text { Scatterplot }
$$

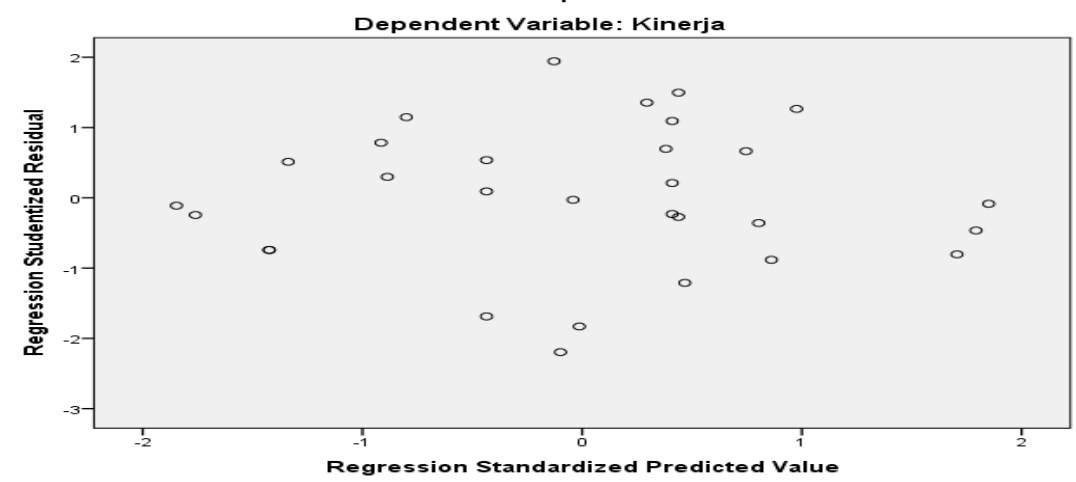

Gambar 4.3

\section{Uji Heteroskedastisitas}

Dari gambar diatas dapat diketahui bahwa titik yang ada tidak membentuk suatu pola tertentu seperti titik-titik menyebar diatas dan dibawah angka 0 pada sumbu Y, maka tidak terjadi heteroskedastisitas.

\section{F. Analisis Statistik Inferensial}

\section{Analisis Regresi Linier Berganda}

Analisis regresi linier berganda digunakan untuk mengetahui pengaruh atau hubungan variable bebas terhadap variable terikat (kinerja karyawan). Analisis regresi berganda dalam penelitian ini menggunakan metode kuadrat terkecil. Adapun hasil pengujiannya dapat dilihat dibawah ini :

Tabel 4.11

Analisis Regresi Linier Berganda

Coefficients ${ }^{\mathrm{a}}$

\begin{tabular}{|c|c|c|c|c|c|c|}
\hline \multirow{2}{*}{\multicolumn{2}{|c|}{ Model }} & \multicolumn{2}{|c|}{ Unstandardized Coefficients } & \multirow{2}{*}{$\begin{array}{c}\begin{array}{c}\text { Standardized } \\
\text { Coefficients }\end{array} \\
\text { Beta }\end{array}$} & \multirow[b]{2}{*}{$\mathrm{t}$} & \multirow[b]{2}{*}{ Sig. } \\
\hline & & B & Std. Error & & & \\
\hline \multirow[t]{3}{*}{1} & (Constant) & 3,345 & 1,212 & & 1,837 & 000 \\
\hline & Motivasi &, 045 & ,201 &, 045 & 4,752 &, 000 \\
\hline & disiplin kerja & 067 & ,248 &, 732 & 3,401 &, 000 \\
\hline
\end{tabular}

a. Dependent Variable: Kinerja 
Sumber: Out put SPSS, data diolah (2015)

Dari hasil perhitungan diatas dapat dibuat sebuah model persamaan regresi linier berganda, yaitu sebagai berikut :

$$
\mathrm{Y}=3,345+0,045 \mathrm{X}_{1}+0,067 \mathrm{X}_{2}
$$

Persamaan tersebut dapat dijelaskan sebagai berikut:

a. Konstanta $\left(\alpha_{0}\right)$ bernilai 3,345 hal ini menunjukkan bahwa jika tidak ada pengaruh variabel motivasi dan disiplin kerja, maka kinerja karyawan akan tetap ada sebesar 3,345 atau $33,45 \%$ variable motivasi dan disiplin kerja mempengaruhi kinerja karyawan.

b. Koefisien regresi $X_{1}\left(\alpha_{1}\right)$ sebesar 0,045 artinya bahwa setiap peningkatan sebesar satu satuan pada variabel motivasi, maka kinerja karyawan akan meningkat sebesar 0,045 satuan. Hal tersebut menunjukkan bahwa faktor motivasi positif terhadap kinerja karyawan.

c. Koefisien regresi $X_{2}\left(\alpha_{2}\right)$ sebesar 0,067 artinya bahwa setiap peningkatan sebesar satu satuan pada variabel disiplin kerja, maka kinerja karyawan akan meningkat sebesar 0,067 satuan. Hal tersebut menunjukkan bahwa faktor disiplin kerja berpengaruh positif terhadap kinerja karyawan.

Dengan demikian berdasarkan analisis regresi linier berganda dapat disimpulkan bahwa kinerja karyawan pada CV Musty Jaya Rantauprapat dipengaruhi oleh faktor motivasi dan disiplin kerja.

\section{Koefisien Determinasi $\left(\mathbf{R}^{2}\right)$}

Pengujian koefisien determinasi $\left(\mathrm{R}^{2}\right)$, dilakukan untuk mengukur persentase kemampuan variable bebas yaitu motivasi dan disiplin kerja dalam menjelaskan perubahan variabel terikat yaitu kinerja karyawan $(\mathrm{Y})$, dimana $0 \leq \mathrm{R}^{2} \leq 1$. Besarnya koefisien determinasi dapat dilihat pada tabel 4.12 berikut ini:

Tabel 4.12

Model Summary ${ }^{b}$

\begin{tabular}{|l|r|r|r|r|}
\hline Model & R & R Square & $\begin{array}{c}\text { Adjusted R } \\
\text { Square }\end{array}$ & $\begin{array}{c}\text { Std. Error of } \\
\text { the Estimate }\end{array}$ \\
\hline 1 &, $823^{\mathrm{a}}$ &, 787 &, 654 & 3.412 \\
\hline
\end{tabular}

a. Predictors: (Constant), disiplin kerja, Motivasi

b. Dependent Variable: Kinerja

Berdasarkan hasil SPSS didapat nilai koefisien determinasi sebesar 0,787. Artinya $78,70 \%$ variabel motivasi dan disiplin kerja mempengaruhi kinerja karyawan dan sisanya sebesar 21,30\% dijelaskan oleh variabel lain.

Dengan demikian model regresi linier berganda ini layak dipakai dalam penelitian, karena sebagian besar variabel terikat dijelaskan oleh variabel-variabel bebas yang digunakan dalam model. 


\section{G. Pengujian Hipotesis \\ 1. Uji parsial (uji t)}

Tabel 4.13

Uji Parsial (uji t)

Coefficients $^{\mathrm{a}}$

\begin{tabular}{|c|c|c|c|c|c|c|}
\hline \multirow{2}{*}{\multicolumn{2}{|c|}{ Model }} & \multicolumn{2}{|c|}{$\begin{array}{c}\text { Unstandardized } \\
\text { Coefficients }\end{array}$} & \multirow{2}{*}{$\begin{array}{c}\text { Standardized } \\
\text { Coefficients }\end{array}$} & \multirow[b]{2}{*}{$\mathrm{t}$} & \multirow[b]{2}{*}{ Sig. } \\
\hline & & $\mathrm{B}$ & Std. Error & & & \\
\hline \multirow[t]{3}{*}{1} & (Constant) & 3,345 & 1,212 & & 1,837 & ,000 \\
\hline & Motivasi & ,045 & ,201 &, 045 & 4,752 & ,000 \\
\hline & $\begin{array}{l}\text { disiplin } \\
\text { kerja }\end{array}$ & ,067 & ,248 & ,732 & 3,401 & ,000 \\
\hline
\end{tabular}

a. Dependent Variable: Kinerja

Sumber: Out put SPSS, data diolah (2016)

1) Uji t variabel motivasi $\left(X_{1}\right)$

$H_{0} \quad$ : Tidak ada pengaruh yang signifikan variabel motivasi $\left(\mathrm{X}_{1}\right)$ secara parsial terhadap kinerja karyawan.

$H_{A}$ : Ada pengaruh yang signifikan variabel motivasi $\left(\mathrm{X}_{1}\right)$ secara parsial terhadap kinerja karyawan

Dengan pengujian dua sisi yang menggunakan tingkat signifikan sebesar $\alpha=5 \%$ dan dengan derajat kebebasan df $(\mathrm{n}-\mathrm{k}-1=30-2-1=27)$ diperoleh t tabel sebesar 1,703. Hasil perhitungan pada regresi linier berganda diperoleh nilai t-hitung sebesar 4,752. Dengan demikian t-hitung lebih besar dari t-tabel $(4,752>1,703)$ maka Ho ditolak Ha diterima, artinya pada variabel motivasi secara parsial mempunyai pengaruh yang signifikan terhadap kinera karyawan.

2). Uji t variabel disiplin kerja $\left(\mathrm{X}_{2}\right)$

$H_{0}$ : Tidak ada pengaruh yang signifikan variabel disiplin kerja $\left(\mathrm{X}_{2}\right)$ secara parsial terhadap kinerja karyawan (Y)

$H_{A}$ : Ada pengaruh yang signifikan variabel disiplin kerja $\left(\mathrm{X}_{2}\right)$ secara parsial terhadap kinerja karyawan (Y)

Dengan pengujian dua sisi yang menggunakan tingkat signifikan sebesar $\alpha=5 \%$ dan dengan derajat kebebasan df $(\mathrm{n}-\mathrm{k}-1=30-2-1=27)$ diperoleh $\mathrm{t}$ tabel sebesar 1,703 . Hasil perhitungan pada regresi linier berganda diperoleh nilai t-hitung sebesar 3,401. Dengan demikian t-hitung lebih besar dari t-tabel $(3,401>1,703)$ maka Ho ditolak Ha diterima, artinya pada variabel disiplin kerja secara parsial mempunyai pengaruh yang signifikan terhadap kinerja karyawan.

\section{Uji serentak (uji F)}


Tabel 4.14

Uji F

ANOVA $^{\mathrm{a}}$

\begin{tabular}{|ll|r|r|r|r|r|}
\hline \multicolumn{2}{|l|}{ Model } & $\begin{array}{c}\text { Sum of } \\
\text { Squares }\end{array}$ & df & Mean Square & F & Sig. \\
\hline 1 & Regression & 202,323 & 2 & 141,162 & 20,248 &, $000^{\mathrm{b}}$ \\
& Residual & 144,467 & 27 & 5,341 & & \\
& Total & 456,800 & 29 & & & \\
\hline
\end{tabular}

a. Dependent Variable: Kinerja

b. Predictors: (Constant), disiplin kerja, Motivasi

Berdasarkan data didapat F-hitung sebesar 20,248 dengan probabilitas F-hitung sebesar 0.000 Hal ini menunjukan bahwa F-hitung lebih besar dari F-tabel yang nilainya 20,248 Karena F-hitung > F-tabel $(20,248>3.35)$ maka Ho ditolak dan Ha diterima. Ini menunjukan bahwa variabel motivasi $\left(\mathrm{X}_{1}\right)$ dan disiplin kerja $\left(\mathrm{X}_{2}\right)$ secara simultan mempunyai pengaruh yang signifikan terhadap kinerja karyawan.

\section{H. Pembahasan}

Dari hasil penelitian yang telah dilakukan penulis maka diperoleh kevalitan data kuesioner dan reliabilitas seluruh instrumennya. Nilai uji validitas diperoleh hasil $t_{\text {hitung }}>t_{\text {tabel }}$. Untuk reliabilitas instrument, kuesioner dinyatakan dapat digunakan untuk pengukuran dalam rangka pengumpulan data dikarenakan $r_{\text {hitung }}>r_{\text {tabel }}$ dan keputusan dinyatakan reliabel dan layak digunakan sebagai alat pengukuran dalam penelitian ini.

Hasil persamaan regresi diperoleh $\mathrm{Y}=3,345+0,045 \mathrm{X}_{1}+0,067 \mathrm{X}_{2}$. Hasil koefisien determinasi diperoleh 0,787. Artinya 78,70\% variabel terikat (kinerja karyawan) dijelaskan oleh variabel bebas dan sisanya dijelaskan oleh variabel lain diluar variabel yang digunakan.

Variabel motivasi $\left(\mathrm{X}_{1}\right)$ dan disiplin kerja $\left(\mathrm{X}_{2}\right)$ secara simultan mempunyai pengaruh yang signifikan terhadap kinerja karyawan sebesar 20,248 dengan probabilitas F-hitung sebesar 0.000 .

\section{KESIMPULAN DAN SARAN}

\section{A. Kesimpulan} berikut :

Berdasarkan hasil penelitian dan pembahasan di muka dapat ditarik kesimpulan sebagai

1. Terdapat pengaruh positif dan signifikan Motivasi Kerja terhadap Kinerja Karyawan pada CV Musty Jaya, hal ini ditunjukkan dengan diperolehnya koefisien korelasinya positif sebesar 0,045 dan koefisien determinasi $r^{2}$ sebesar 0,000 dan harga thitung sebesar 4,752 $>\mathrm{t}$ tabel1,684 pada taraf signifikansi 5\%.

2. Terdapat pengaruh positif dan signifikan Disiplin Kerja terhadap Kinerja Karyawan pada CV Musty Jaya, hal ini ditunjukkan dengan diperolehnya koefisien korelasinya positif sebesar 0,067 dan koefisien determinasi $\mathrm{r}^{2}$ sebesar 0,000 dan harga thitung sebesar 3,401 $>$ ttabel 1,684 pada taraf signifikansi 5\%.

3. Terdapat pengaruh positif dan signifikan Motivasi Kerja dan Disiplin Kerja secara bersama-sama terhadap Kinerja Karyawan pada CV Musty Jaya, hal ini ditunjukkan dengan diperolehnya koefisien korelasi ganda positif sebesar 0,823 dan koefisien determinasi ganda $\mathrm{R}^{2}$ sebesar 0,787 dan nilai Fhitung sebesar 20,248 > Ftabel 2,84 pada taraf signifikansi $5 \%$. 


\section{B. Saran}

Berdasarkan hasil penelitian di atas, peneliti memberikan saran sebagai berikut :

1. Perlu adanya peningkatan Kinerja Karyawan dalam hal ketepatan waktu untuk menyelesaikan tugas yang telah menjadi tanggung jawab mereka. Sehingga pekerjaan selesai dengan tepat waktu dan dapat meningkatkan Kinerja Karyawan.

2. Perlu adanya peningkatan kemampuan atau keterampilan kerja karyawan, pemberian gaji dan hubungan sesama karyawan sehingga dapat meningkatkan Motivasi Kerja dan Kinerja Karyawan.

3. Perlu adanya pelatihan kerja sehingga dapat meningkatkan keterampilan kerja

4. Perlu adanya peningkatan motivasi kerja karyawan dalam melaksanakan tugas yang telah menjadi tanggung jawab mereka sehingga dapat meningkatkan Disiplin Kerja dan juga meningkatkan Kinerja Karyawan.

5. Dengan memberikan tambahan insentif kepada karyawan yang memiliki kinerja lebih sehingga karyawan termotivasi dalam melakukan pekerjaan.

\section{DAFTAR PUSTAKA}

Arikunto, Suharsini, 2012, Prosedur Suatu Penelitian, Penerbit:Ghalia Indonesia, Jakarta

Hasibuan, H. Malayu S.P. 2008, Manajemen Sumber Daya Manusia. Jakarta : Bumi Aksara. Ivancevich, dkk. 2008. Perilaku dan Manajemen Organisasi. Jakarta : Erlangga

Kartono, Kartoni, 2008, Pemimpin dan kepemimpinan, Jakarta, Raja Grafindo Persada.

Mangkunegara, Anwar Prabu. 2000. Manajemen Sumber Daya Manusia Perusahaan. PT Remaja Rosdakarya. Bandung

Masu'ud, 2006, "Persepsi Sosial Tentang Kredibilitas Pemimpin”, Sinergi Kajian Bisnis dan Manajemen, Vol.3, No.1. Hal 51-65

Robbins dan Judge. 2007. Perilaku Organisasi, Jilid 2. Jakarta : Salemba Empat

Ruky S. Achmad, 2006, Sumber Daya Berkualitas, Mengubah Visi Menjadi Realita, cetakan kedua, Penerbit : Gramedia Pustaka Utama, Jakarta

Saputra, Sigit Adri. 2010. Pengaruh Kompensasi, Kepuasan Kerja, dan Motivasi Kerja Terhadap Kinerja Karyawan Bagian Akuntansi. Fakultas Ekonomi Sekolah Tinggi Ilmu Ekonomi Perbanas. Surabaya

Santoso, Singgih. (2007). Menguasai STATISTIK di ERA INFORMASI Dengan SPSS 15. Elex Media Komputindo Gramedia, Jakarta.

Sugiyono, 2010. Metode Penelitian Bisnis, Penerbit Alfabeta, Bandung

Siagian, Sondang, P., 2009, Manajemen Sumber Daya Manusia, edisi pertama, cetakan kedua, Penerbit : Bumi Aksara, Jakarta

Wijaya, Tony. 2012. Cepat Menguasai SPSS 20 untuk olah dan Interpretasi Data. Cahaya Atma Pustaka. Yogyakarta

Winardi. 2006. Kepemimpinan Dalam Manajemen. Rineka Cipta. Jakarta 